\title{
Effect of Soil Moisture Stress on Onion (Allium cepa L) Production and Water Productivity at Melkassa in the Central Rift Valley of Ethiopia
}

\author{
Ketema Tezera $^{1 *}$ and Abraham Woldemichael ${ }^{2}$ \\ 1 Ethiopian Institute of Agricultural Research (EIAR), Melkassa Agricultural Research Centre, Ethiopia \\ 2 School of Bio-Systems and Environmental Engineering, Institute of Technology, Hawassa University, \\ Hawassa, Ethiopia \\ *Corresponding author's email: ketematezera29@gmail.com PO Box 436
}

\begin{abstract}
Water availability is becoming a critical issue in Ethiopia in arid and semi-arid areas mainly in Rift Valley. Field experiment was carried out at Melkassa Agricultural Research Center, Ethiopia during growing season 2017/8 under furrow irrigation system and eight irrigation treatments replicated three times in a randomized complete block design. Hence, the objective of this study was to establish critical moisture stress threshold level for improving production and water productivity of irrigated onion under limited water resource condition. In the study, irrigation treatments consisted full supply of irrigation $100 \% \mathrm{ET}_{\mathrm{C}}$ (control) and seven stress levels were imposed on onion nafis variety through growth stages. Obtained results revealed that, the highest seasonal water requirement value of $422.1 \mathrm{~mm}$ was by the $100 \% \mathrm{ET}_{\mathrm{C}}$ while, the lowest value of $198.8 \mathrm{~mm}$ was by $40 \% \mathrm{ET}_{\mathrm{C}}$. Analysis of the data obtained showed significant $(\mathrm{p}<0.05)$ effects of soil moisture stress treatments on onion growth parameters. Analysis of the data obtained showed significant $(p<0.05)$ effects of soil moisture stress treatments on onion bulb yield and yield components. The study revealed, yield response factor (Ky) for the onion was showed there is yield reduction as crop stressed. Highest Marginal rate of return was obtained from $70 \%$ ETc of $24914.3 \%$ and decrease to $90 \%$ ETc of $2155.4 \%$. The study has concluded that moisture stress through growth stage significantly influenced onion bulb yield. Therefore, the critical stress level of the onion from this study could be irrigated at $75 \% \mathrm{ET}_{\mathrm{C}}$ to increase WP without a significant yield reduction and economically visible. The study suggests that moisture stress strategy should be adopted for optimum yield and maximum water productivity without a significant yield reduction.
\end{abstract}

Keywords: Deficit irrigation, furrow Irrigation, Moisture stress, Onion, Water productivity

DOI: $10.7176 / \mathrm{JNSR} / 13-3-02$

Publication date: February $28^{\text {th }} 2022$

\section{INTRODUCTION}

Water is an essential natural gift to sustain life. Agriculture is the major consumer of freshwater (Gontia and Tiwari, 2010). Irrigated agriculture makes a major contribution to food security, producing nearly $40 \%$ of food and agricultural commodities in the world with only $16 \%$ of cultivated land (Bos et al., 2008). Irrigated areas have almost doubled in recent decades and contributed much to the growth in agricultural productivity over the last 50 years. Irrigated agriculture uses more than $70 \%$ of the water withdrawn from the earth's rivers; in developing countries, the proportion exceeds $80 \%$ (FAO, 2015).

Ethiopia has enormous potential to produce the crop throughout the year both for domestic use and export market. Onion (Allium cepa L.) is one of the most important cultivated vegetable crops commercially grown., it is widely cultivated as a source of income by many farmers in many parts of the country. Onion production also contributes to the commercialization of the rural economy and creates many off-farm jobs (Olani and Fikre, 2010). Onion production is increasing from time to time. During the 2013/2014 cropping season, the total area under onion production was estimated to be $24,375.7$ ha with an average yield of about 9.02 tons per hectare and estimated total production of greater than 2 million tons (CSA, 2014).

Water scarcity intensifies in many regions of the world; better management of water is becoming a pressing issue (Lorite et al, 2007). It is the most severe constraint for the development of agriculture, particularly in arid and semiarid areas. Moisture stress being a new irrigation strategy that utilizes water resources efficiently is a suitable option. When, crops are subjected to a certain level of water stress during specific growth stages or throughout the whole growing season. It is without significant reduction in yields compared with the benefits gained through diverting the saved water to irrigate other crops (Kipkorir et al., 2001). Reduction of the water used for crop production is a means of increasing water productivity and reducing water scarcity (Hoekstra, 2017). This would provide an incentive for water users to reduce their consumption per unit of product down to a certain reasonable reference level. The reduction of irrigation water in irrigated agriculture to the threshold level relates to improving the increasing water productivity (Molden et al., 2010), thus relieving water scarcity (Mekonnen and Hoekstra, 2014; Zhuo et al., 2016; Zwart et al., 2010). Irrigation water use reduction in irrigated crop production 
can be achieved through a range of measures, including a change in mulching practice or in irrigation technique or strategy. Chukalla et al. (2015) studied the effectiveness of different combinations of irrigation techniques, irrigation strategy and mulching practice in terms of water use reduction. Hence, due to the limited availability of irrigation water, different crops responses differently to water stress depending on crop sensitivity. Therefore, determination of stress level that yields higher water productivity without significant crop yield reduction is important technology through establishing water stress threshold level for onion under limited soil moisture condition and the following three objectives have done.

$\checkmark \quad$ To identify critical stress level for mean production in different stress scenarios

$\checkmark$ To determine onion yield reduction and moisture withholding gradient

$\checkmark \quad$ To evaluate the effect of soil moisture stress on water productivity

\section{MATERIALS AND METHODS}

\section{Description of the study area}

The study was conducted at Melkassa Agricultural Research Center (MARC) experimental site during 2017/18 dry season. The area is located in the Central Rift Valley of Ethiopia. It is geographically located between latitude of $8^{0} 24^{\prime}$ to $8^{0} 26^{\prime} \mathrm{N}$, longitude of $39^{0} 19^{\prime}$ to $39^{0} 19^{\prime} \mathrm{E}$ and the mean altitude of the area is $1550 \mathrm{~m}$.a.s.l. It is located about $107 \mathrm{~km}$ to the East of Addis Ababa, capital city of Ethiopia.

Loam and clay loam soil textures are the dominant soils, which is classified as Lithosols with pH of 7. Longterm $(1977$ - 2017) climatic record from station, average annual rainfall in the area is $824.9 \mathrm{~mm}$. The climate of the area is characterized as semi-arid with uni-modal low and erratic rainfall pattern. Kiremt season have got more rainfall about $67.4 \%$ of the total rainfall of the area occurs from June to September, with peak month of July and August. The mean maximum and minimum monthly rainfall is 204.2 and $9.6 \mathrm{~mm}$ occurs in the month of August and November, respectively (Figure 1). The mean maximum temperature varies from 26.3 to $31.0{ }^{\circ} \mathrm{C}$ while the mean minimum temperature varies from 10.4 to $16.4{ }^{0} \mathrm{C}$, with the average of $21.3 \quad{ }^{0} \mathrm{C}$.

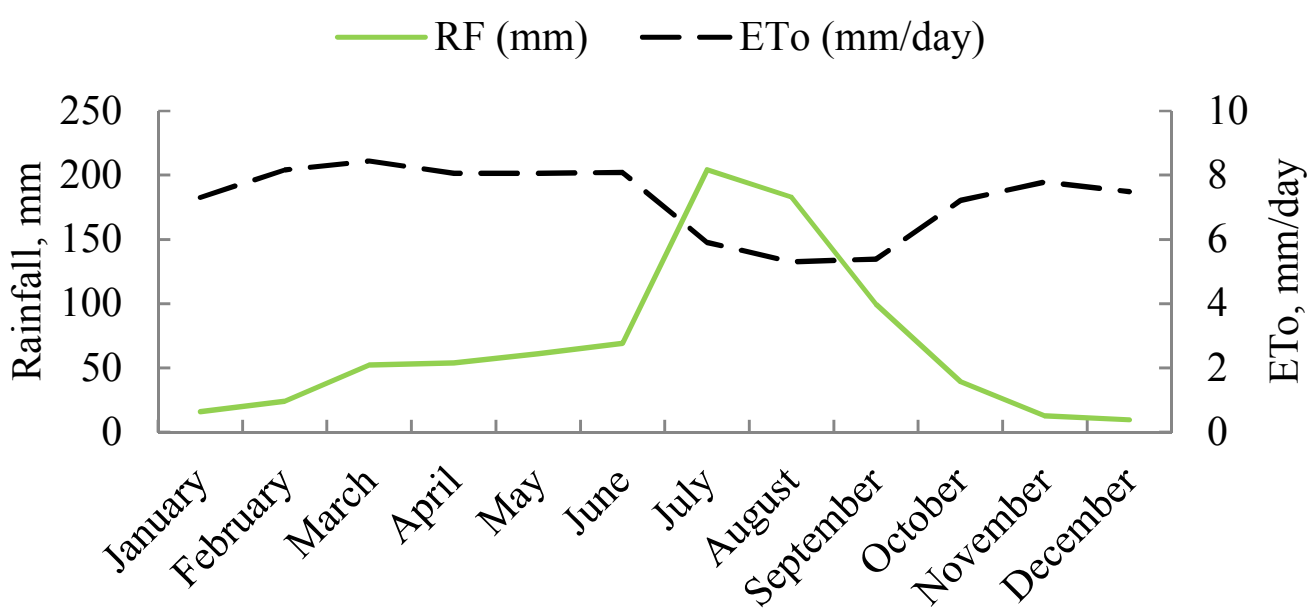

Month

Figure 1: Long-term monthly climatic water balance of the study area (MARC)

\section{Experimental design and procedure}

The experiment contains one non stress and seven moisture stress treatments as $100 \%$ of the crop water requirement (ETc) (control), 90\%ETc, $80 \% \mathrm{ETc}, 75 \% \mathrm{ETc}, 70 \% \mathrm{ETc}, 60 \% \mathrm{ETc}, 50 \% \mathrm{ETc}$ and $40 \% \mathrm{ETc}$. The stress treatments were designed by lowering the amount of irrigation water application. The different moisture stress levels and control treatments were laid out in randomized complete block design (RCBD) with three replications. The experimental field will be divided into 24 plots and each plot size was $3 \mathrm{~m} \mathrm{x} 4 \mathrm{~m}$ dimension (12 $\mathrm{m}^{2}$ plot area) to accommodate five furrows with spacing of $60 \mathrm{~cm}$. Each plot consisted of four ridges and five furrows. The blocks have a buffer zone of $1.2 \mathrm{~m}$ from water supplying canal and plots were separated by $2 \mathrm{~m}$ from each other to eliminate influence of lateral flow of water.

Onion (Allium cepa $L$ ) variety nafis (franciscana) were used as seed material. The recommended seeding rate is $5 \mathrm{~kg} / \mathrm{ha}$ and $60 \mathrm{~g}$ of seeds for a size of $1 \mathrm{~m} \mathrm{X} 5 \mathrm{~m}$ seedbed nursery and prepared accordingly at MARC in September, 2017. The seedling was transplanted to experimental plots after 50 days. Seedling developed at nursery was irrigated and uprooted for transplanting to the experimental field in November, 2017. Onion is known by two row plant so transplanting was done with spacing of $40 \mathrm{~cm}, 20 \mathrm{~cm}$ and $10 \mathrm{~cm}$ spacing of row plant (i.e, plant row spacing across furrow was $40 \mathrm{~cm}$, across ridge was $20 \mathrm{~cm}$ and along the ridge $10 \mathrm{~cm}$ between plants). Each plots 
were fertilized with once application of (DAP) during transplanting only and split application of Urea at transplanting and 15 days after transplanting as topdressing with the rate of $200 \mathrm{~kg} / \mathrm{ha}$ and $100 \mathrm{~kg} / \mathrm{ha}$, respectively (Olani and Fikre, 2010).

Composite soil sample of the onion root zone collected from experimental field diagonally for soil physical and chemical analysis. The irrigation scheduling was done based on the optimum irrigation treatment (100\% ETC) and stressed treatments received lower amount based on their levels on the same irrigation date. Daily ETo was computed using CROPWAT 8.0 model based on the daily actual weather data collected from weather station at the Center. Crop coefficient, optimum depletion level and root depth was adopted from FAO Irrigation and Drainage Paper 56 (FAO, 1998). Based on the rainfall recorded at MARC agro-meteorological service, effective rainfall during the season was determined using the CROPWAT 8.0 model on a daily basis and deducted from the net irrigation depth of next irrigation. Irrigation water applied to each experimental plot was measured using 3inch Parshall flume.

\section{Data collection}

Samples were selected systematically in the two central ridges randomly ( $4 \mathrm{~m} \mathrm{x} 1.2 \mathrm{~m}$ or $4.8 \mathrm{~m}^{2}$ area). Randomly five plants were collected for growth and yield component data. The crop was harvested in March 2018, as $80 \%$ of the bulbs become completely matured, which is evident by the collapse of 20 to $50 \%$ of the neck tissue and falling of the tops. Harvesting was done manually by uprooting the onion bulbs. After harvesting, roots are trimmed and the tops cut away by using sickle and bulbs of each plot was collected in sack separately and tagged properly. Finally, bulb yield and yield component were collected and recorded separately.

Water productivity was calculated based on the Chandrasekaran et al., 2010 formula using equation 1.

Where: WP -Water productivity $\left(\mathrm{kg} / \mathrm{m}^{3}\right)$

$$
\mathrm{WP}=\frac{\mathrm{Ya}}{\mathrm{Twu}} \ldots \ldots \ldots \ldots \text { (1) }
$$

Ya -Actual yield (kg/ha)

Twu -Seasonal applied irrigation water plus effective Rainfall $\left(\mathrm{m}^{3} / \mathrm{ha}\right)$

The Yield response factor was determined based on the ratio of relative yield decrease to relative evapotranspiration deficit expressed in decimal, based on FAO, 2002 formula using equation 2.

Where: $\mathrm{k}_{\mathrm{y}}$-yield response factor

$$
K_{y}=\frac{1-\left(\frac{Y_{a}}{Y_{m}}\right)}{1-\left(\frac{E T_{a}}{E T_{m}}\right)} \ldots \ldots \ldots \ldots
$$

$\mathrm{Y}_{\mathrm{a}}$-actual yield of each treatment $(\mathrm{kg} / \mathrm{ha})$

$\mathrm{Y}_{\mathrm{m}}$-maximum yield from full irrigation treatment $(\mathrm{kg} / \mathrm{ha})$

$\mathrm{ET}_{\mathrm{a}}$-actual evapotranspiration of each treatment $(\mathrm{mm})$

$\mathrm{ET}_{\mathrm{m}}$-maximum evapotranspiration by full irrigation treatment $(\mathrm{mm})$

For economic evaluation of the total return, net benefit, marginal return rate and cost benefit ratio using the different amount of water applied, the Partial Budget Analysis (PBA) was used following the CIMMYT procedure (CIMMYT, 1988). The net income was calculated by subtracting total variable cost production from total return (Kuboja and Temu, 2013) and is computed as equation 3:

$\mathrm{NI}=\mathrm{TR}-\mathrm{TVC}$

The collected data were statistically analyzed using statistical analysis system (SAS) version 9.0 statistical package using procedure of general linear model for the variance analysis. Mean comparisons were executed using least significant difference (LSD) at 5\% probability level when treatments show significant difference to compare difference among treatments mean.

\section{RESULTS AND DISCUSSIONS}

\section{Soil and water properties of the experimental site}

Physical soil properties analysis showed that the average composition of clay, silt and sand percentages were 26.5, 40 and $33.5 \%$, respectively. Thus, according to the USDA soil textural classification, the particle size distribution of the experimental site revealed that the soil textural class is loam soil, which is suitable for onion. The bulk density results varied from $1.06 \mathrm{~g} / \mathrm{cm}^{3}$ at the upper root zone $(0-15 \mathrm{~cm})$ to $1.26 \mathrm{~g} / \mathrm{cm}^{3}$ at the lower root zone layer $(45-60 \mathrm{~cm})$. The average weighted bulk density of the experimental site was $1.16 \mathrm{~g} / \mathrm{cm}^{3}$. Average moisture content on weight base at field capacity (FC) (1/3 bar) and PWP (15 bar) of onion root depth were $36.8 \%$ and $22.1 \%$, respectively. Volumetric TAW was $103.4 \mathrm{~mm}$ with the onion root depth of $0.6 \mathrm{~m}$ and readily available water, with optimum depletion level of $25 \%(\mathrm{p}=0.25)$, was calculated as $25.8 \mathrm{~mm}$ as presented and summarized in Table 1 . 
Table 1: Analysis of physical properties of soil of experimental site

\begin{tabular}{|c|c|c|c|c|c|c|c|c|}
\hline \multirow{3}{*}{$\begin{array}{c}\text { Soil } \\
\text { depth } \\
(\mathrm{cm})\end{array}$} & \multicolumn{8}{|c|}{ Soil physical properties } \\
\hline & \multicolumn{3}{|c|}{$\begin{array}{c}\text { Particle size } \\
\text { distribution }\end{array}$} & $\begin{array}{l}\text { Textural } \\
\text { class }\end{array}$ & $\begin{array}{l}\text { Bulk density } \\
(\mathrm{g} / \mathrm{cm} 3)\end{array}$ & $\begin{array}{l}\text { FC mass } \\
\text { base }(\%)\end{array}$ & $\begin{array}{l}\text { PWP mass } \\
\text { base }(\%)\end{array}$ & $\begin{array}{l}\text { TAW volume } \\
\text { base }(\mathrm{mm})\end{array}$ \\
\hline & $\begin{array}{l}\text { Clay } \\
(\%)\end{array}$ & $\begin{array}{l}\text { Silt } \\
(\%)\end{array}$ & $\begin{array}{l}\text { Sand } \\
(\%)\end{array}$ & & & & & \\
\hline $0-15$ & 26.5 & 45.0 & 28.5 & Loam & 1.06 & 33.8 & 20.8 & 20.7 \\
\hline $15-30$ & 24.0 & 42.5 & 33.5 & Loam & 1.15 & 36.5 & 21.1 & 26.6 \\
\hline $30-45$ & 29.0 & 35.0 & 36.0 & $\begin{array}{l}\text { Clay } \\
\text { loam }\end{array}$ & 1.19 & 39.3 & 23.5 & 28.2 \\
\hline $45-60$ & 26.5 & 37.5 & 36.0 & Loam & 1.26 & 37.7 & 22.9 & 28.0 \\
\hline Average & 26.5 & 40.0 & 33.5 & Loam & 1.16 & 36.825 & 22.075 & 25.8 \\
\hline
\end{tabular}

Source: Own data, 2017

The result of soil chemical analysis showed that, the average $\mathrm{pH}$ value of the soil is nearly neutral (6.74-7.12).

Hence, onion can grow outstanding in this soil condition and the finding is in line with Olani and Fikre (2010) which conclude that $\mathrm{pH}$ range suitable for onion is between 6.0 and 8.0. The soil has an average electrical conductivity of $0.26 \mathrm{dS} / \mathrm{m}$ through $60 \mathrm{~cm}$ soil profile, which is below the threshold value for yield reduction, i.e. $1.2 \mathrm{dS} / \mathrm{m}$ (Smith et al, 2011). The percentage of OM, OC and TN content of the soil were 3.3, 1.91 and 0.16, respectively.

The analysis of applied irrigation water showed that $\mathrm{pH}$ value of 7.51 and $\mathrm{ECw}$ value of $0.46 \mathrm{dS} / \mathrm{m}$ were obtained (Table 2). According to Bryan et al. (2007), the irrigation water is classified in terms of $\mathrm{pH}$ less than 7 low, 7 to 8 slight to moderate and greater than 8 severe. Thus the obtained result of irrigation water $\mathrm{pH}$ value was classified in the range of slight to moderate.

Table 2: Analysis of chemical properties of soil and water

\begin{tabular}{cccccc}
\hline & pH & EC $(\mathrm{dS} / \mathrm{m})$ & $\begin{array}{c}\text { Soil chemical properties } \\
\text { Total organic matter }(\%)\end{array}$ & OC $(\%)$ & TN $(\%)$ \\
\hline $0-15$ & 6.74 & 0.215 & 4.29 & 2.49 & 0.2145 \\
$15-30$ & 7.07 & 0.229 & 3.90 & 2.26 & 0.1950 \\
$30-45$ & 7.08 & 0.305 & 3.04 & 1.76 & 0.1520 \\
$45-60$ & 7.12 & 0.299 & 1.95 & 1.13 & 0.0975 \\
Average & 7.00 & 0.260 & 3.30 & 1.91 & 0.1600 \\
\hline pH & 7.510 & Irrigation Water chemical properties & \\
EC $(\mathrm{dS} / \mathrm{m})$ & 0.364 &
\end{tabular}

Source: Own data, 2017

\section{Crop water requirement of onion}

The seasonal crop water requirement of onion determined based on the seasonal water application depth from transplanting to harvest and vary based on the moisture level of treatments. To enable establishment of the onion common irrigation depth of $26.5 \mathrm{~mm}$ applied for all treatments from transplanting before treatment intervention start. The highest irrigation water application was $398.6 \mathrm{~mm}$ obtained from the control treatment (T1) and the minimum was $175.34 \mathrm{~mm}$ from highly stressed treatment (T8). The highest gross irrigation seasonal water requirement that calculated by applying 60\% field application efficiency obtained from T1 was $664.3 \mathrm{~mm}$ and the lowest was $292.2 \mathrm{~mm}$ from $\mathrm{T} 8$.

During the experiment there were, rainfall data recorded then the effective precipitation was calculated. The total result of calculated effective rainfall was $23.5 \mathrm{~mm}$ that reduced from net irrigation depth during the next irrigation treatment application.

The result showed that seasonal optimal onion water demand is $422.1 \mathrm{~mm}$ and the result in line with MOA (2011). The result of onion seasonal water demands of $330 \mathrm{~mm}$ obtained from $75 \% \mathrm{ET}_{\mathrm{C}}$ at which yield reduction was insignificant as compared to $100 \% \mathrm{ET}_{\mathrm{C}}$. Based on this result, the producers can plan to harvest water and area of land for onion production. 
Table 3: Seasonal net irrigation water depth applied for each treatment

\begin{tabular}{ccccc}
\hline Treatments & $\begin{array}{c}\text { Total crop } \\
\text { water } \\
\text { requireme } \\
\text { nt, } \\
(\mathrm{mm})\end{array}$ & $\begin{array}{c}\text { Irrigation during } \\
\text { treatment application } \\
(\mathrm{mm})\end{array}$ & $\begin{array}{c}\text { Total irrigation water } \\
\text { requirement, }(\mathrm{mm})\end{array}$ & $\begin{array}{c}\text { Gross irrigation water } \\
\text { requirement, mm }\end{array}$ \\
\hline $\begin{array}{c}\mathrm{T} 1(100 \% \\
\left.\mathrm{ET}_{\mathrm{C}}\right)\end{array}$ & 422.1 & 372.1 & 398.60 & 664.3 \\
$\mathrm{~T} 2\left(90 \% \mathrm{ET}_{\mathrm{C}}\right)$ & 384.9 & 334.9 & 361.39 & 602.3 \\
$\mathrm{~T} 3\left(80 \% \mathrm{ET}_{\mathrm{C}}\right)$ & 347.7 & 297.7 & 324.18 & 540.3 \\
$\mathrm{~T} 4\left(75 \% \mathrm{ET}_{\mathrm{C}}\right)$ & 329.1 & 279.1 & 305.58 & 509.3 \\
$\mathrm{~T} 5\left(70 \% \mathrm{ET}_{\mathrm{C}}\right)$ & 310.5 & 260.5 & 286.97 & 478.3 \\
$\mathrm{~T} 6\left(60 \% \mathrm{ET}_{\mathrm{C}}\right)$ & 273.3 & 223.3 & 249.76 & 416.3 \\
$\mathrm{~T} 7\left(50 \% \mathrm{ET}_{\mathrm{C}}\right)$ & 236.1 & 186.1 & 212.55 & 354.3 \\
$\mathrm{~T} 8\left(40 \% \mathrm{ET}_{\mathrm{C}}\right)$ & 198.8 & 148.8 & 175.34 & 292.2 \\
\hline
\end{tabular}

\section{Effects of Deficit Irrigation on Growth Parameters}

Analysis of variance (ANOVA) of green leaves number shown that there were significant $(\mathrm{P}<0.05)$ influence by different levels of moisture stress. The results revealed the maximum leaf number 13 obtained from optimal irrigation (T1) and there was no significant difference among T1, T2 and T3. The minimum leaf number of 5 obtained from high stressed treatment (T8) and it was significantly different from all treatments.

Moreover, results shows that irrigation application level has significant effect on vegetative growth. This indicated that as irrigation application level decreased from non-stress (T1) to high stress level (T8) the number of leaves was also decreased. The result obtained in line with the observations in other irrigation studies on onion by different researchers. Al-Moshileh (2007), reported that number of leaves decreased with decreasing soil moisture level. Similarly, Metwally (2011) indicated that the higher depth of irrigation water applied, the higher vegetative parameters produced.

ANOVA of plant height of onion shows that there was significant $(\mathrm{P}<0.05)$ influence by different levels of moisture stress. The highest plant height $68.1 \mathrm{~cm}$ was recorded from control treatment (T1). Application of irrigation water levels at $90 \% \mathrm{ET}_{\mathrm{C}}, 80 \% \mathrm{ET}_{\mathrm{C}}$ and $75 \% \mathrm{ET}_{\mathrm{C}}$ statistically has no significant difference as compared to control treatment. The minimum plant height $45.4 \mathrm{~cm}$ was recorded from treatment $\mathrm{T} 8$ and this was significantly different from all other treatments except T7 (Table 4).

ANOVA of leaf height of onion shows that there was significant $(\mathrm{P}<0.05)$ influence because of different levels of moisture stress. The highest leaf height $62.9 \mathrm{~cm}$ was recorded from control treatment $\mathrm{T} 1$ and statistically has no significant difference with an irrigation application of $90 \% \mathrm{ET}_{\mathrm{C}}$ and $80 \% \mathrm{ET}_{\mathrm{C}}$ treatments. The minimum leaf height $38.7 \mathrm{~cm}$ was recorded from treatment $\mathrm{T} 8$ and this was significantly different from all other treatments except T7.

In general, the results indicated that both plant and leaf height of onion decreased as soil moisture level decrease from optimum irrigation $\left(100 \% \mathrm{ET}_{\mathrm{C}}\right)$ to low soil moisture level $\left(40 \% \mathrm{ET}_{\mathrm{C}}\right)$. This indicated that plant and leaf height of onion received maximum applied water was taller than onion that received minimum amount of applied water (Table 4).

The results revealed plant and leaf height is directly associated with the amount of irrigation water applied. The results are agreements with observation in other irrigation studies on onion by different researchers. Metwally (2011) indicated that the higher water supply resulted in the higher vegetative parameters (plant and leaf height) and Al-Moshileh (2007) reported that with increasing soil water supply plant height were significantly increased in the tested growing seasons. This finding is in line with the results of Aklilu (2009) and Takele (2009) who reported that plant height of pepper decreased with decreased irrigation levels and also increase with the irrigation water level. 
Table 4: Effect of moisture stress on growth parameters

\begin{tabular}{lccc}
\hline \multicolumn{1}{c}{ Treatments } & Leaf number per plant & Plant height, cm & Leaf height, cm \\
\hline $\mathrm{T} 1\left(100 \% \mathrm{ET}_{\mathrm{C}}\right)$ & $12.83 \mathrm{a}$ & $68.13 \mathrm{a}$ & $62.90 \mathrm{a}$ \\
$\mathrm{T} 2\left(90 \% \mathrm{ET}_{\mathrm{C}}\right)$ & $12.23 \mathrm{a}$ & $67.13 \mathrm{a}$ & $60.70 \mathrm{ab}$ \\
$\mathrm{T} 3\left(80 \% \mathrm{ET}_{\mathrm{C}}\right)$ & $11.83 \mathrm{ab}$ & $66.77 \mathrm{a}$ & $57.57 \mathrm{abc}$ \\
$\mathrm{T} 4\left(75 \% \mathrm{ET}_{\mathrm{C}}\right)$ & $10.87 \mathrm{~b}$ & $64.80 \mathrm{ab}$ & $56.27 \mathrm{bc}$ \\
$\mathrm{T} 5\left(70 \% \mathrm{ET}_{\mathrm{C}}\right)$ & $9.40 \mathrm{c}$ & $58.27 \mathrm{bc}$ & $51.67 \mathrm{~cd}$ \\
$\mathrm{~T} 6\left(60 \% \mathrm{ET}_{\mathrm{C}}\right)$ & $8.03 \mathrm{~d}$ & $52.83 \mathrm{~cd}$ & $47.87 \mathrm{de}$ \\
$\mathrm{T} 7\left(50 \% \mathrm{ET}_{\mathrm{C}}\right)$ & $6.90 \mathrm{~d}$ & $49.80 \mathrm{de}$ & $44.73 \mathrm{ef}$ \\
$\mathrm{T} 8\left(40 \% \mathrm{ET}_{\mathrm{C}}\right)$ & $5.23 \mathrm{e}$ & $45.37 \mathrm{e}$ & $38.73 \mathrm{f}$ \\
$\mathrm{CV}$ & 6.94 & 6.61 & 7.04 \\
$\mathrm{LSD}(0.05)$ & 1.1756 & 6.849 & 6.4802 \\
\hline
\end{tabular}

Means followed by different letters in a column differ significantly and those followed by the same letter are not significantly different according to LSD at $\mathrm{P}<0.05$ level of significance.

\section{Yield and yield component response to moisture stress}

Results analyzed for total yield, marketable yield, bulb diameter, average bulb weight and dry matter percentage summarized and presented in Table below.

Table 5: Effect of moisture stress on yield and yield components

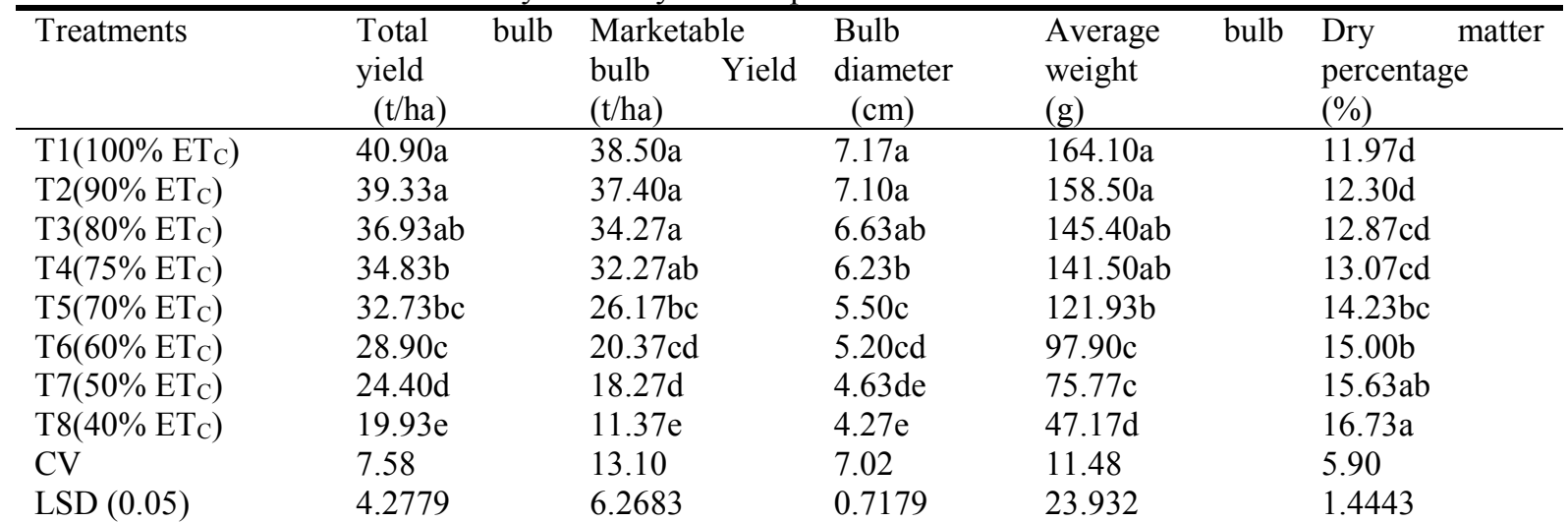

Means followed by different letters in a column differ significantly and those followed by the same letter are not significantly different according to LSD at $\mathrm{P}<0.05$ level of significance.

Yield from non-stressed treatments (T1) was the highest of 40.9 ton/ha while the most stressed treatment (T8) had the lowest yield of 19.9 ton/ha (Table 5). The ANOVA across the treatments revealed that moisture stress level significant $(\mathrm{p}<0.05)$ influence on onion bulb yield. Coefficient of determination of 0.976 was strong and indicate strong relationship between moisture stress level and bulb yield; meaning yield affected by water as a variable (Figure 2). This means moisture stress had a strong influence on onion total bulb yield and the effect was insignificant among T1, T2 and T3. In contrary, bulb yield recorded under T6, T7 and T8 was significantly different from each other.

The result obtained from non-stress treatment was in agreement with the potential yield of the variety released (Zeleke and Derso, 2015). When water stress is imposed on the crop at varying levels, soil moisture tends to be depleted by the roots leading to reduced physiological activities which in turn affect root development. If replenishment delays as in prolonged stress treatment, the crop wilts or recovers partially resulting in reduced yield and its components (Kirda and Kanber, 1999). The results also showed that the effect of various treatments, influenced yields to different levels and the degree of recovery also varied according to the intensity of water stress (Table 5).

In general, yield decreased with increasing water stress signifying that the crop is subjected to high stress. This showed the response of onion crop to moisture stress level and applying deficit irrigation bulb yield of onion was decreased. The higher yield was obtained in full irrigation and reduced significantly from non-stress to high stressed level. The result is in conformity with those obtained by Zayton (2007), Samson and Ketema (2007), Kumar et al. (2008), Owusu-Sekyre and Anodh (2011).

ANOVA for marketable bulb yield of onion indicated that there was significant $(\mathrm{P}<0.05)$ effect because of 
different levels of moisture stress treatments. The highest marketable bulb yield of 38.5 ton/ha was obtained from the control treatment (T1) and the lowest value of 11.4 ton/ha was obtained from high stress treatment (T8). The results also showed that yield reduction was not significant among treatments which received higher amounts of irrigation water T1, T2, T3 and T4. This means that imposing with low stress up to $75 \% \mathrm{ET}_{\mathrm{C}}$ through growth stage has no significant effect on marketable bulb yield reduction. In contrary, there was significant difference between treatments which received minimum amounts of irrigation water $\mathrm{T} 7$ and $\mathrm{T} 8$ that imposed high stress to onion.

In general, the results indicated that marketable bulb yield of onion decreased as soil moisture level decrease from optimum irrigation $\left(100 \% \mathrm{ET}_{\mathrm{C}}\right)$ to low soil moisture level $\left(40 \% \mathrm{ET}_{\mathrm{C}}\right)$. This indicated that onion bulbs received maximum applied water was larger than onion bulbs that received minimum amount of applied water.

The results revealed marketable bulb yield is directly associated with the amount of irrigation water applied. The results are agreements with observation in other irrigation studies on onion by different researchers. Igbadun et al. (2012) reported that the bulb yield of onion was highly decreased through regulated deficit irrigation. Similar results were also reported by Kloss et al. (2012) who showed that dealing with improvement of water productivity is closely related to the irrigation practice of regulated deficit irrigation and has a direct effect on yield that is, if the amount of water applied decreases intentionally the crop yield will decrease. In contrary, Samson and Ketema (2007) found that applying regulated deficit irrigation in some growth stages of onion did not significantly reduce the yield.

Statistical analysis made on yield component indicated that different moisture stress treatments had a significant $(\mathrm{P}<0.05)$ effect on bulb diameter. The largest mean diameter of $7.2 \mathrm{~cm}$ was recorded from $\mathrm{T} 1 \mathrm{which}$ received optimum amount of applied water while treatment T8 was recorded the smallest diameter of $4.3 \mathrm{~cm}$ that received the lowest amount of applied water. Onion bulb diameter was determined as an indicator of size and it was found to be significantly influenced by water stress level. The results also showed that the reduction of bulb size was not significant difference among treatments which received higher amounts of irrigation water T1, T2, and T3. This means that imposing with low stress up to $80 \% \mathrm{ET}_{\mathrm{C}}$ through growth stage has no significant effect on bulb diameter as compared to $100 \% \mathrm{ET}_{\mathrm{C}}$ and not significantly different from treatment which received $75 \%$ ET $_{C}$ amounts of applied water. There was also not significant different between treatments which received minimum amounts of applied water T7 and T8 that imposed high stress to onion. In contrary, there was significant difference between treatments which received $75 \% \mathrm{ET}_{\mathrm{C}}$ and $70 \% \mathrm{ET}_{\mathrm{C}}$ amounts of applied water $\mathrm{T} 7$ and $\mathrm{T} 8$ that imposed high stress to onion. The coefficient of determination of 0.96 analysis between diameter and irrigation water applied was strong and indicate that the increase in bulb diameter in different treatments was attributed to increase in the quantity of water hence quantity of water applied influences onion bulb size.

Results indicated that bulb diameter varied proportionally with the quantity of irrigation water applied. Therefore there is a linear relationship between bulb size and quantity of irrigation water applied. This is an indication that larger onion sizes can be produced when applied water is more and the moisture stress affect the size of the onion.

The results indicate that it is possible to produce different size of bulb based on size required by applying different amount of water. A similar effect of varied applied irrigation water levels on size of onion bulbs (the largest from $100 \% \mathrm{ET}_{\mathrm{C}}$ and the smallest from $40 \% \mathrm{ET}_{\mathrm{C}}$ ) was observed by Mebrahtu et al. (2018). David et al. (2016) concluded that bulb size varied proportionally with the quantity of irrigation water applied (the largest from the $100 \% \mathrm{ET}_{\mathrm{C}}$ and the smallest from $50 \% \mathrm{ET}_{\mathrm{C}}$ ). These results emphasize that adequate soil moisture content through the growing period encouraged the vegetative growth of the plant and enhanced the development of large and medium bulb size which is considered to be marketable.

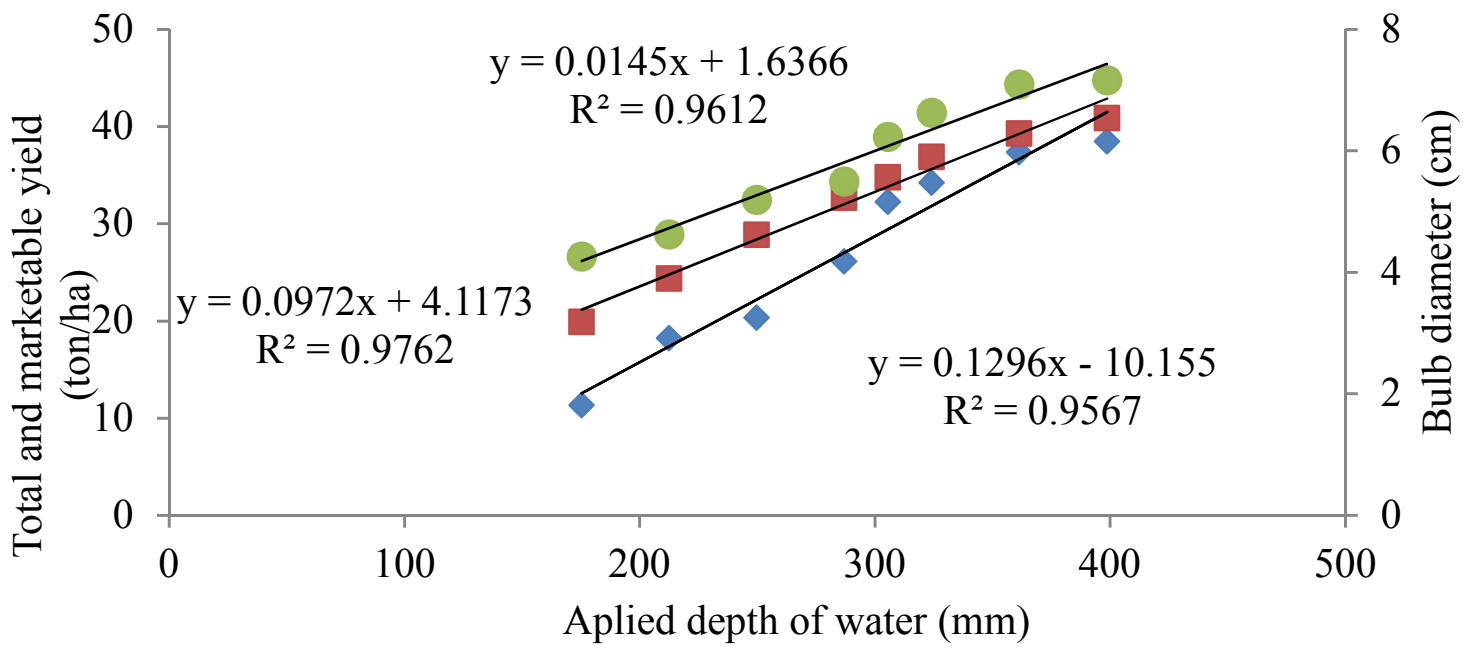

Figure 2: Effect of moisture stress on mean onion bulb diameter. 
Statistical analysis made on yield components indicated that different moisture stress treatments had a significant $(\mathrm{P}<0.05)$ effect on average weight of onion bulbs with a coefficient of determination of 0.95 which suggests a direct relationship between stress level and weight. The highest average weight of bulbs of $164.1 \mathrm{~g}$ was obtained from treatment which received the highest supply of water (T1) while that received the lowest quantity (T8) produced minimum average bulb weight of $47.2 \mathrm{~g}$. The results also showed that reduction in bulb weight was not significant difference among treatments which received higher amounts of irrigation water T1, T2, T3 and T4. This means that imposing with low stress up to $75 \% \mathrm{ET}_{\mathrm{C}}$ through growth stage has no significant effect on weight of bulb reduction. In contrary, there was significant difference between treatments which received minimum amounts of irrigation water T7 and T8 that imposed high stress to onion.

In general, weight was reduced significantly with decreasing applied irrigation, which may be due to water shortage. This shows response of crop to moisture stress and as applied water increased the average weight of onion bulbs increased and it is high at no moisture stress level. The result is in conformity with those obtained by Zayton (2007) and Mane et al., 2014)

ANOVA for percentage of dry matter content of onion bulbs showed that there was significant $(\mathrm{P}<0.05)$ influence because of different levels of moisture stress. As indicates in Table 6, the bulb dry matter percentage obtained at T1, T2, T3 and T4 were not significantly different from each other. Percentage of dry matter content obtained from non-stressed treatments (T1) was lowest of $11.97 \%$ while the most stressed treatment (T8) had the highest percentage of bulb dry matter content of $16.73 \%$. This implies that the percentage of moisture content of bulbs decrease as soil moisture stress increase. The results also shows that the dry matter content in bulbs increased with increase in water application level because of bulb size.

A similar effect of varied applied irrigation water levels on dry matter content of onion was observed by Kumar et al. (2007) studied the effect of water application and fertigation on onion dry matter production and reported that irrigation at high water supply and nutrient level onions produced higher dry matter yield. Sorensen and Grevsen (2001) also concluded that high moisture stress level resulted in higher dry matter percentage in bulbs.

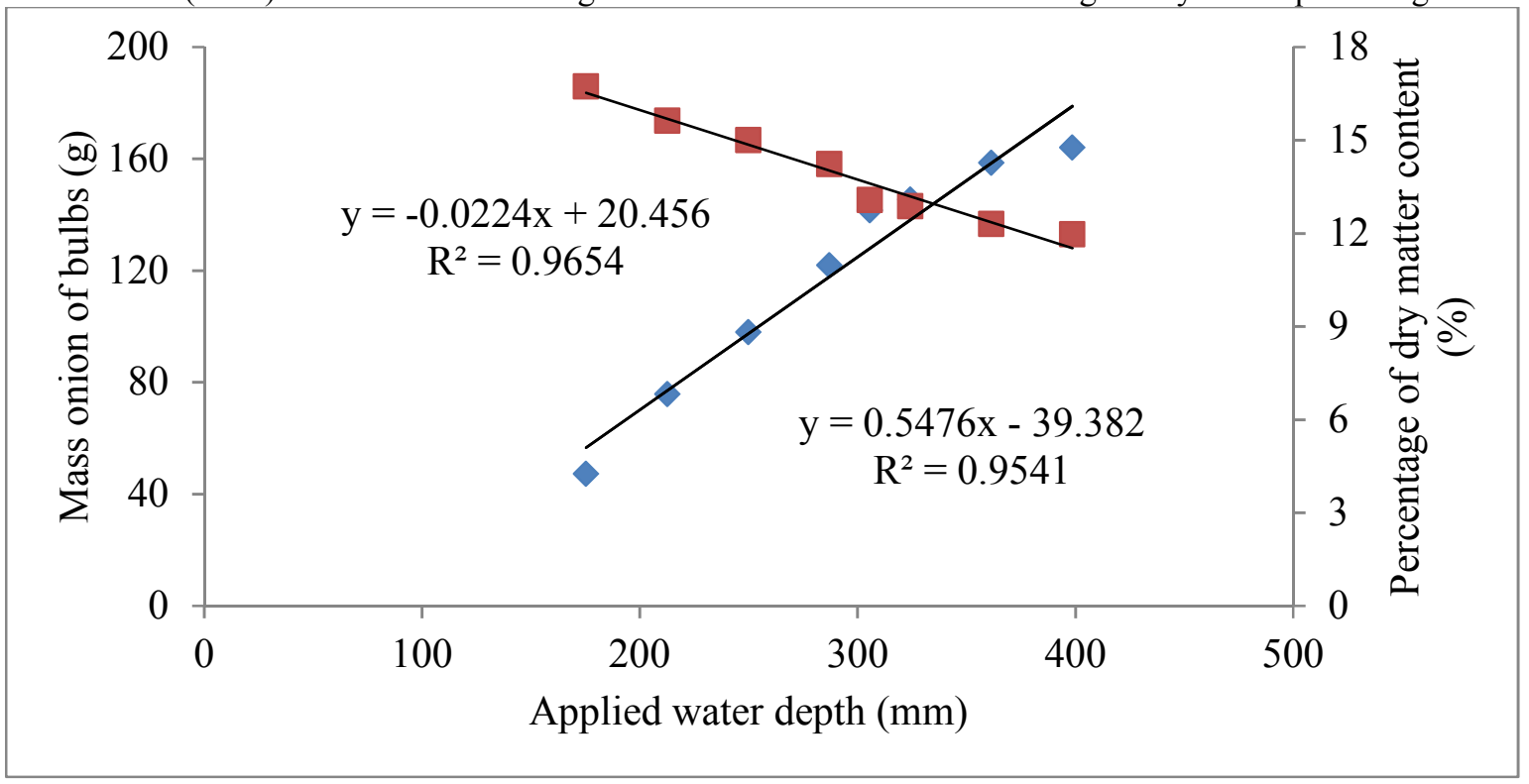

Figure 3: Effect of moisture stress on percentage of dry matter content of onion bulbs

\section{Effect of Moisture Stress on Water Productivity}

Optimal irrigation treatment (T1) was used as the reference point for comparison of irrigation treatments in saving water. The net saving in irrigation water from T2, T3, T4, T5, T6, T7 and T8 were 10, 20, 25, 30, 40, 50, and 60\% respectively. This implies that as water stress level increases water saving also increases. The highest value of WP $\left(12.6 \mathrm{kgm}^{-3}\right)$ was obtained from treatment $\mathrm{T} 8$ while the lowest value $10.37 \mathrm{kgm}^{-3}$ was obtained from treatment $\mathrm{T} 1$, respectively. It shows that WP values increase as moisture stress level increase.

The result obtained in line with the observations in other irrigation studies on onion by different researchers. Samson and Ketema (2007) reported that deficit irrigations increased the water productivity of onion. Similarly, both Mebrahtu et al. (2018) and Sarkar et al. (2008) reported that irrigation water use efficiency was higher at lower levels of available soil moisture.

Relative yield reduction was initially low and then it increased with increasing moisture stress level (Table 6). WP of T4 and T5 at 11.7 and $11.73 \mathrm{kgm}^{-3}$ were almost the same while the difference in marketable bulb yield was 6.1 ton/ha .Water saving from both treatments T4 and T5 was $25 \%$ and $30 \%$ respectively. Optimum yield is 
achieved by balancing between WP, yield reduction and water saving. These findings indicate that T4 results in $25 \%$ and $14.8 \%$ water save and yield reduction without substantial negative effect on irrigation water productivity of the crop which implies yield reduction was not proportion to water saving.

Table 6: Water productivity and Irrigation water use of irrigation treatments

\begin{tabular}{lrcc}
\hline Treatments & $\mathrm{WP}, \mathrm{kg} / \mathrm{m}^{3}$ & Water saved, $\%$ & Yield reduction, $\%$ \\
\hline T1 $\left(100 \% \mathrm{ET}_{\mathrm{C}}\right)$ & 10.37 & 0 & 0.0 \\
$\mathrm{~T}_{2}\left(90 \% \mathrm{ET}_{\mathrm{C}}\right)$ & 10.37 & 10 & 3.8 \\
$\mathrm{~T} 3\left(80 \% \mathrm{ET}_{\mathrm{C}}\right)$ & 11.70 & 20 & 9.7 \\
$\mathrm{~T}\left(75 \% \mathrm{ET}_{\mathrm{C}}\right)$ & 11.73 & 25 & 14.8 \\
$\mathrm{~T}_{5}\left(70 \% \mathrm{ET}_{\mathrm{C}}\right)$ & 11.83 & 30 & 20.0 \\
$\mathrm{~T} 6\left(60 \% \mathrm{ET}_{\mathrm{C}}\right)$ & 12.17 & 40 & 29.3 \\
$\mathrm{~T}_{7}\left(50 \% \mathrm{ET}_{\mathrm{C}}\right)$ & 12.33 & 50 & 40.3 \\
$\mathrm{~T}_{8}\left(40 \% \mathrm{ET}_{\mathrm{C}}\right)$ & 12.60 & 60 & 51.3 \\
\hline
\end{tabular}

Producing at T4 saves $25 \%$ irrigation water but resulted in bulb yield reduction of 6.1 ton/ha. The water saved is adequate to expand more than 0.31 ha of land and produce additional 10.08 tons of onions giving a total of 42.35 tons with the same quantity of water which could have yielded 40.9 tons/ha at full irrigation treatment. These results showed that moisture stress affects yields negatively without substantially reducing yields at stress level T4. At this level water saving (25\%) resulted in lower yield reduction $(14.8 \%)$ as compared to high moisture stressed treatments but higher than low moisture stressed treatments. The figure below shows that as you hold more water the yield penalty also more.

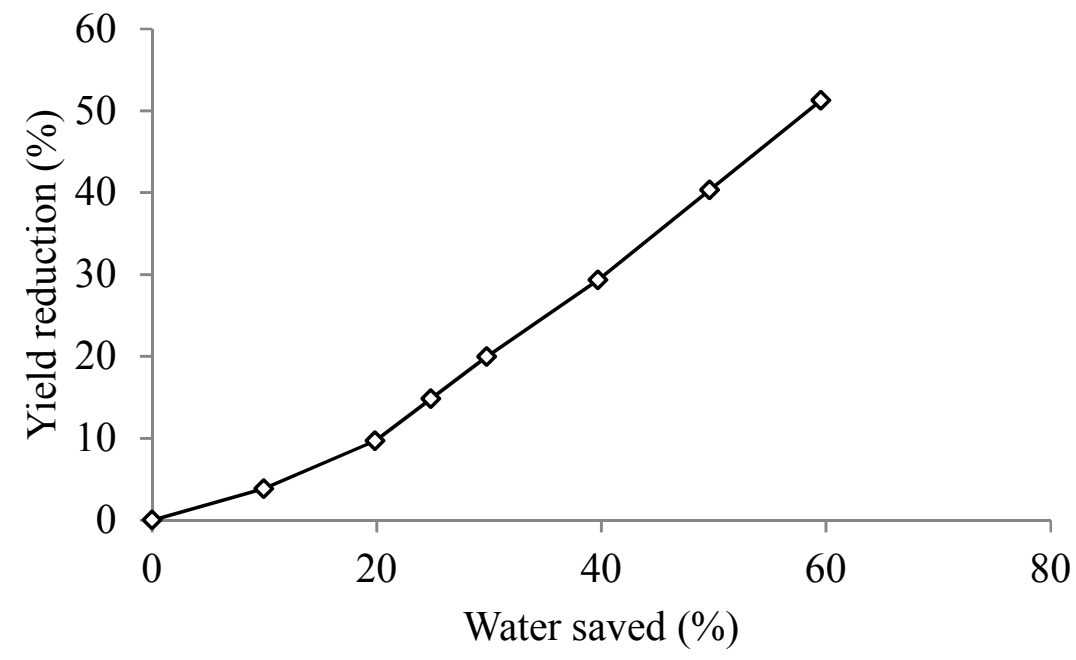

Figure 4: Optimum production of onion using water saving and yield reduction.

\section{Effect of Moisture Stress on Yield Response Factor}

The results indicated that yield response factor ranges from 0.43 to 0.97 for stressed treatments. The lower values of yield response factor associated with treatments that obtained maximum amount of water and higher values associated with treatments that obtained minimum amount of water. The study reveals that lower yield response factor was associated with lower stressed treatments in which statistically similar yield was obtained with that of the optimum irrigation of $100 \% \mathrm{ET}_{\mathrm{C}}$ treatment. The seasonal yield response factor obtained from the moisture stress treatments T2, T3, T4, T5, T6, T7 and T8 were $0.43,0.55,0.67,0.76,0.83,0.92$ and 0.97 respectively. 
Table 7: Effect of different moisture stress levels on yield response factor

\begin{tabular}{|c|c|c|c|c|c|}
\hline TRT & $\begin{array}{l}\text { Yield, } \\
\mathrm{kg} / \mathrm{ha}\end{array}$ & $\begin{array}{l}\text { ETc, } \\
\text { Mm }\end{array}$ & $1-\left(\frac{\mathrm{Ya}}{\mathrm{Ym}}\right)$ & $1-\left(\frac{\mathrm{ETa}}{\mathrm{ETm}}\right)$ & $K_{y}=\frac{1-\left(\frac{Y_{a}}{Y_{m}}\right)}{1-\left(\frac{E T_{a}}{E T_{m}}\right)}$ \\
\hline $\mathrm{T} 1\left(100 \% \mathrm{ET}_{\mathrm{C}}\right)$ & 40900 & 422.10 & 0.00 & 0.00 & - \\
\hline $\mathrm{T} 2\left(90 \% \mathrm{ET}_{\mathrm{C}}\right)$ & 39333 & 384.89 & 0.04 & 0.09 & 0.43 \\
\hline $\mathrm{T} 3\left(80 \% \mathrm{ET}_{\mathrm{C}}\right)$ & 36933 & 347.68 & 0.10 & 0.18 & 0.55 \\
\hline $\mathrm{T} 4\left(75 \% \mathrm{ET}_{\mathrm{C}}\right)$ & 34833 & 329.08 & 0.15 & 0.22 & 0.67 \\
\hline $\mathrm{T} 5\left(70 \% \mathrm{ET}_{\mathrm{C}}\right)$ & 32733 & 310.47 & 0.20 & 0.26 & 0.76 \\
\hline $\mathrm{T} 6\left(60 \% \mathrm{ET}_{\mathrm{C}}\right)$ & 28900 & 273.26 & 0.29 & 0.35 & 0.83 \\
\hline $\mathrm{T} 7\left(50 \% \mathrm{ET}_{\mathrm{C}}\right)$ & 24400 & 236.05 & 0.40 & 0.44 & 0.92 \\
\hline $\mathrm{T} 8\left(40 \% \mathrm{ET}_{\mathrm{C}}\right)$ & 19933 & 198.84 & 0.51 & 0.53 & 0.97 \\
\hline
\end{tabular}

Different studies revealed that yield response factor varies for different crop type and stress condition. However, yield response factors have been found to be dependent on locations. Kipkorir et al., (2002) found the seasonal Ky of onion to be 1.28 while Doorenbos and Kassam (1979) gave the parameter as 1.1. The result of the experimental site indicated that effect of moisture stress treatments influence onion yield. When $\mathrm{Ky}>1$, the crop response is very sensitive to water deficit with proportional larger yield reductions; $\mathrm{Ky}<1$, the crop is more tolerant to water deficit, and recovers partially from stress, exhibiting less than proportional reductions in yield with reduced water use; $\mathrm{Ky}=1$, the yield reduction is directly proportional to reduced water use (Doorenbos and Kassam, 1979). Since the obtained $\mathrm{Ky}<1$, the crop is more tolerant to water deficit, and recovers partially from stress, exhibiting less than proportional reductions in yield with reduced water use. But the result among the treatments showed as moisture stress increased the sensitivity of yield increased.

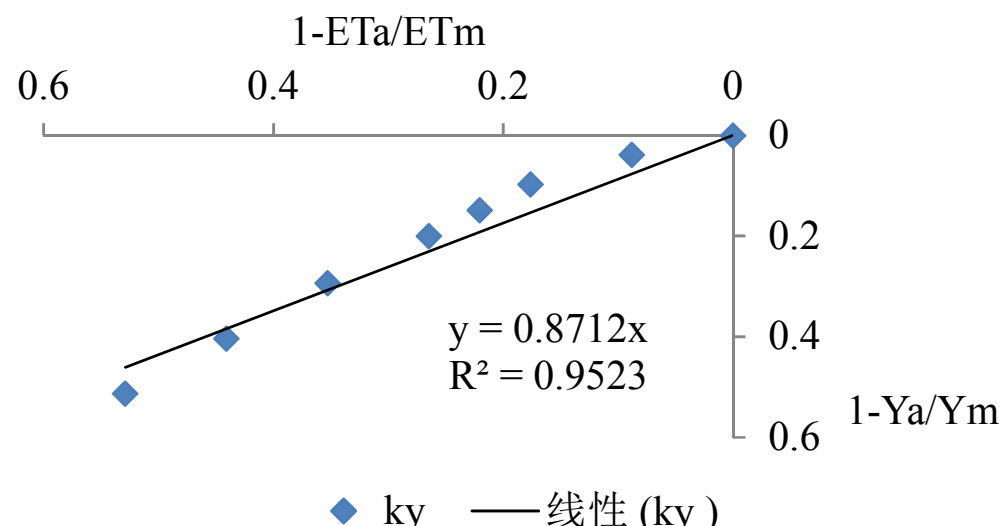

Figure 5: Relationship between relative yield decrease and relative crop evapotranspiration through growth stages of onion. 
Economic Analysis of Onion Response to Moisture Stress Level

Table 8: Partial budgeting MRR and B/C analysis for economic onion production

\begin{tabular}{ccccccccc}
\hline Trt. & I $\left(\mathrm{m}^{3} / \mathrm{ha}\right)$ & $\begin{array}{c}\text { UMY } \\
(\mathrm{kg} / \mathrm{ha})\end{array}$ & $\begin{array}{c}\text { AMY } \\
(\mathrm{kg} / \mathrm{ha})\end{array}$ & TR $(\mathrm{birr} / \mathrm{ha})$ & $\begin{array}{c}\text { TVC } \\
\text { (birr/ha) }\end{array}$ & NI (birr/ha) & MRR (\%) & B/C \\
\hline T1 & 6643.3 & 38500 & 34650.0 & 225225 & 3056.4 & 222168.6 & - & 72.7 \\
T2 & 6023.2 & 37400 & 33660.0 & 218790 & 2771.0 & 216019.0 & 2155.4 & 78.0 \\
T3 & 5403.0 & 34267 & 30840.3 & 200462 & 2485.7 & 197976.2 & 6323.8 & 79.6 \\
T4 & 5092.9 & 32267 & 29040.3 & 188762 & 2343.1 & 186418.9 & 8101.4 & 79.6 \\
T5 & 4782.8 & 26167 & 23550.3 & 153077 & 2200.4 & 150876.5 & 24914.3 & 68.6 \\
T6 & 4162.7 & 20367 & 18330.3 & 119147 & 1915.1 & 117231.9 & 11792.0 & 61.2 \\
T7 & 3542.5 & 18267 & 16440.3 & 106862 & 1629.8 & 105232.2 & 4205.7 & 64.6 \\
T8 & 2922.3 & 11367 & 10230.3 & 66497 & 1344.5 & 65152.5 & 14047.4 & 48.5 \\
\hline
\end{tabular}

Note: Trt = Treatment, $I=$ Applied irrigation, $U M Y=$ Unadjusted marketable yield, AMY = adjusted marketable yield, $T V C=$ Total variable cost, $T R=$ Total return, $N I=$ net income, $M R R=$ Marginal rate of return, $B / C=$ Benefit cost ratio, Adjustment coefficient was 10\%, Field price of water and onion bulb was 1 birr $/ 100 \mathrm{~m}^{3}$ and 6.5 birr, respectively.

The detail evaluation of the economic analysis of irrigation treatments has shown that there was increasing trend of net income (NI) for increase in water application level. It is clear that water saving at high application level is very low, though control treatment $\left(\mathrm{T}_{1}\right)$ has the highest NI. This is because unit price of irrigation water of $1 \mathrm{birr} / 100 \mathrm{~m}^{3}$, the rate state farms in the area pay for irrigation water, was very low. As a result, the direct impact of water saving generated NI was very low for a hectare of land per season which means nil value from hectare. Therefore, to clearly notice the impact of irrigation water saving due to irrigation treatments, it is apparent to evaluate each tested irrigation protocol in terms of the change in income due to saved irrigation water. T8 had the highest benefit obtained from saved irrigation water. All stressed treatments had also an economic advantage of birr from saved irrigation water per hectare over non stressed irrigation treatments (T1).

The extra income which can be obtained from unit increment in investment cost described as marginal rate of return (MRR). The highest MRR was $24914.3 \%$ obtained at T5. This means that for every 1 birr invested on applied water of $286.97 \mathrm{~mm}$, farmers can expect to recover 1birr and obtained additional of 249.143 birr. This shows that $\mathrm{T} 5$ can be the most preferable type of irrigation treatment to all other tested irrigation treatments as it can generate more profit per extra addition investment in water limited areas. However, imposing moisture stress to onion MRR shows that an increasing trend up to T4 in which marketable bulb yield reduction is not significant. The highest benefit cost ratio $(\mathrm{B} / \mathrm{C})$ obtained from $\mathrm{T} 3$ and $\mathrm{T} 4$. The results revealed $\mathrm{B} / \mathrm{C}$ were increasing from optimal irrigation up to $75 \% \mathrm{ET}_{\mathrm{C}}$ and decreasing trend with stress level. Minimum $\mathrm{B} / \mathrm{C}$ ratio obtained from $\mathrm{T} 8$. Maximum yield may be obtained with the fulfillment of the entire crop water requirements. However, practicing irrigation with moisture stress level can save irrigation water which increases the irrigated area, frequency of cultivation or release more water for downstream. The results in line with Ali et al., (2007) who reported water saved by DI can be used to irrigate more land on the same farm or in the water user's community, which given the high opportunity cost of water, and may largely compensate for the economic loss due to yield reduction.

\section{CONCLUSION AND RECOMMENDATIONS}

\section{Conclusion}

This study revealed that onion production and productivity is directly related to moisture stress and water productivity. It appears the control treatment (full irrigation) is not advisable for arid and semi-arid areas since it has small productivity due to high water demand. Hence, water management of irrigated onion is very essential in growth stage with suitable water restriction to get higher yield from a drop of irrigation water.

Moisture stress levels influence the growth parameters of onion. Moreover, reducing irrigation water from $100 \% \mathrm{ET}_{\mathrm{C}}$ to $40 \% \mathrm{ET}_{\mathrm{C}}$ leads to significantly reduced plant height, leaf height and leaf number. Yield and yield components like marketable bulb yield, bulb diameter and mean mass were also significantly reduced while dry matter percentage increase due to reduction of irrigation water amount. However, marketable bulb yield of onion was statistically similar until the irrigation water reduced to 25 percent of full irrigation.

However, water productivity was increased as irrigation water applied reduced. This reveal that the highest water productivity value obtained from more moisture stressed and the lowest was from non-stressed treatment. The study further reveals, yield response factor was gradually increased as moisture stress level increased. The minimum and maximum yield response factor was obtained at $90 \% \mathrm{ET}_{\mathrm{C}}$ and $40 \% \mathrm{ET}_{\mathrm{C}}$, respectively. This reveal, yield response factor $(\mathrm{Ky})$ for onion was showed there is yield reduction as crop stressed.

To sum up, moisture stress treatments that imposed to onions influence yields in a positive linear trend with decreasing amount of applied irrigation water and increasing water stress reaching optimum crop marketable yield at $25 \% \mathrm{ET}_{\mathrm{C}}$ continuous water stress thereby saving 25 percent irrigation water. It was further concluded that production at this level optimizes water productivity without significantly affecting onion marketable bulb yield. 
It was also found that moisture stress influenced the size and mean mass of fresh onion bulbs, with low size variation of the fresh bulbs. Therefore, moisture stress strategy can be used in deciding onion sizes to produce for a particular prevailing market and bulb yield penalty because of amount of irrigation water saved.

\section{Recommendations}

Based on the above findings, the following recommendation can be forwarded for further consideration and improvement of onion production and water productivity particularly in the study area and in general in the country.

$>$ Irrigation water management through moisture stress strategies should be declared with appropriate stress level restriction during growth stages to achieve optimum yield and save water.

$>$ Soil moisture stressing technology is recommended for use by farmers and extension workers to optimize onion production and maximize crop water productivity by applying at $75 \% \mathrm{ET}_{\mathrm{C}}$ through growth stages with holding of $25 \%$ water requirement.

$>$ Suggesting of practicing irrigation with moisture stress level save irrigation water and it increases frequency of cultivation, irrigated area or use for other purpose of income generation.

$>$ Similar studies should be carried out with different irrigation levels of moisture stress to ascertain conclusively the influence of the same study on yields and water productivity. In addition the permissible depletion level $(p=0.25)$ has to be rechecked.

\section{REFERENCES}

Aklilu Mesfin. (2009). Effects of mulching and depth of irrigation application on water use efficiency and productivity of pepper under gravity drip irrigation, MSc. Thesis, Department of Irrigation Engineering, Haramaya University, Ethiopia.

Ali, M.H., M.R. Hoque, A.A. Hassan and A.Khair. (2007). Effects of deficit irrigation on yield, water productivity and economic returns of wheat. Journal of Water Management 92: 151-161.

Allen, R., L.A. Pereira, D. Raes and M. Simth. (1998). Crop evapotranspiration guidelines for computing crop water requirement. FAO Irrigation and Drainage Paper Number 56. FAO, Rome, Italy.

Al-Moshileh, A. (2007). Effects of planting date and irrigation water level on onion (Allium cepa L.) production under Central Saudi Arabian conditions. Journal of Basic and Applied Sciences 8(1): 14-28.

Asfaw Zeleke and Eshetu Derso (eds), (2015). Production and management of vegetable crops in Ethiopia, December 2015, Addis Ababa, Ethiopia. Ethiopian Institute of Agricultural Research, Addis Ababa, Ethiopia; KOPIA Ethiopia Centre, Addis Ababa, Ethiopia. Printed at Eth-Cana Printing Press 149 pages Addis Ababa, Ethiopia.

Bos, M. G., R. A. L. Kselik, R. G. Allen and D. J. Molden. (2008). Water requirements for irrigation and the environment. Springer, Dordrecht, Netherlands.

Bryan, G., A. Donald and G. Robert. (2007). Managing irrigation water quality for crop production, Washington state university.

Chandrasekaran, B., K. Annadurai and E. Somasundaram. (2010). A textbook of agronomy. New Age International. New Delhi, India.

Chukalla, A. D., M. S. Krol, and A. Y. Hoekstra. (2015). Green and blue water footprint reduction in irrigated agriculture: effect of irrigation techniques, irrigation strategies and mulching. Hydrol. Earth Syst. Sci., 19, 4877-4891.

CIMMYT (International Maize and Wheat Improvement Center). (1988). From agronomic data to farmer recommendations: An economics-training manual. Completely Revised Edition. CIMMYT, D.F, Mexico.

CSA (Central Statistical Agency). (2014). Agriculture sample survey. Central Statistical Agency.Vol.1, Addis Ababa, Ethiopia.

David, K., C. Emmanuel and K. John. (2016). Effects of deficit irrigation on yield and quality of onion crop. Journal of Agricultural Science 8(3): 1916-9760.

FAO (Food and Agriculture Organization of the United Nations). (1998). Crop evapotranspiration guidelines for computing crop water requirements. Irrigation and Drainage Paper 56. FAO, Rome.

FAO (Food and Agriculture Organization). (2002). Deficit irrigation practice. Water Reports Paper 22. FAO, Rome, Italy.

Geerts, S and D. Raes. (2009). Deficit irrigation as an on-farm strategy to maximize water productivity. Journal of Agricultural Water Management 9:1275-1284.

Gontia N. K. and K. N. Tiwari. (2010). Estimation of crop coefficient and evapotranspiration of wheat (Triticum aestivum) in an irrigation command using remote sensing and GIS. Water Resources Management 24(7):1399-1414.

Hoekstra, A. Y. (2017). Water Footprint Assessment: Evolvement of a New Research Field. Water Resource Management 31: 3061-3081.

Igbadun H.E., A.A. Ramalan and E. Oiganji. (2012). Effects of regulated deficit irrigation and mulch on yield, 
water use and crop water productivity of onion in Samaru, Nigeria. Journal of Agricultural Water Management 109:162-169.

Kipkorir, E.C., D. Raes and J. Labadie. (2001). Optimal allocation of short-term irrigation supply. Journal of Irrigation and Drainage System 15: 247-267.

Kipkorir, E.C., D. Raes and B. Massawe. (2002). Seasonal water production functions and yield response factors for maize and onion in Perkerra, Kenya. Agric. Water Management 56: 229-240.

Kirda, C. and R. Kanber. (1999). Water, no longer a plentiful resource, should be used sparingly in irrigated agriculture. In: C. Kirda P. Moutonnet C. Hera and D.R. Nielsen, eds. Crop yield response to deficit irrigation. Kluwer Academic Publishers. Dordrecht. The Netherlands.

Kloss S, R. Pushpalatha, KJ. Kamoyo and Schütze. (2012). Evaluation of crop models for simulating and optimizing deficit irrigation systems in arid and semi-arid countries under climate variability. Journal of Water Resource Management 26(4): 997-1014.

Kumar, S., M. Imtiyaz and A. Kumar. (2007). Effect of differential soil moisture and nutrient regimes on postharvest attributes of onion (Allium cepa L.). Science of Horticulture 112: 121-129.

Kumar, S., M. Imtiyaz, and A. Kumar. (2008). Variable irrigation and fertigation effects on response of onion (Allium cepa L.) in a semi-arid environment. Indian Journal of Agricultural Science 78(3) : 203-207.

Lorite, I.J., L. Mateos, F. Orgaz, E. Fereres. (2007). Assessing deficit irrigation strategies at the level of an irrigation district. Journal of Agricultural Water Management 91: $51-60$.

Mane, M.S., G.G. Kadam and S.T. Patil. (2014). Effect of irrigation levels on vegetative growth and yield characteristics in white onion (Allium cepa L.) in Konkan region. International Journal of Agricultural Engineering 7(2): 422-426.

Mebrahtu Yemane, Abraham Woldemichael and Solomon Habtu. (2018). Response of onion (Allium cepa L) to deficit irrigation under different furrow irrigation water management techniques in Raya Valley, Northern Ethiopia. African Journal of Plant Science 12(5): 105-113.

Mekonnen, M. M. and A. Y. Hoekstra, (2014). Water footprint benchmarks for crop production: A first global assessment, Ecol. Indic., 46, 214-223.

Metwally, A.K. (2011). Effect of water supply on vegetative growth and yield characteristics in onion (Allium cepa L.). Australian Journal of Basic and Applied Science 5(12): 3016-3023.

MoA (Ministry of Agriculture). (2011). Natural Resources Management Directorates. Guideline on irrigation agronomy. Addis Ababa, Ethiopia.

Molden, D., Oweis, T., Steduto, P., Bindraban, P., Hanjra, M. A., and Kijne, J, (2010). Improving agricultural water productivity: between optimism and caution, Agr. Water Manage., 97, 528-535.

Olani Nikus and Fikre Mulugeta. (2010). Onion seed production techniques. A manual for extension agents and seed producers. FAO-crop diversification and marketing development project. FAO, Rome, Italy.

Owusu-Sekyere, J.D., P. Asante and P. Osei-Bonsu. (2010). Water requirement, deficit irrigation and crop coefficient of hot pepper (Capsicum frutescens) using irrigation interval of four days. ARPN Journal of Agricultural and Biological Science 5 (5): 72-78.

Samson Bekele and Ketema Tilahun. (2007). Regulated deficit irrigation scheduling of onion in a semiarid region of Ethiopia. Journal of Agricultural Water Management 89:148-152.

Sarkar, S., S.B. Goswami, S. Mallick and M.K. Nanda. (2008). Different indices to characterize water use pattern of micro-sprinkler irrigated onion (Allium cepa L.). Journal of Agricultural Water Management. 95: 625-632.

Smith, R., A. Biscaro, M. Cahn, O. Daugovish, E. Natwick, J. Nunez, E. Takele, and T. Turini. (2011). Freshmarket bulb onion production in California. Publication 7242. University of California, Agricultural and Natural Resource Center. California.

Sorensen, J.N. and K. Grevsen. (2001). Sprouting in bulb onions (Allium cepa L.) as influenced by nitrogen and water stress. Journal of Horticultural Science and Biology 76(4): 501-506.

Takele Gadissa. (2009). Effect of drip irrigation levels and planting methods on yield and water use efficiency of pepper in Bako, Western Oromia, MSc. Thesis, Department of Irrigation Engineering, Haramaya University, Ethiopia.

Zayton, A.M. (2007). Effect of soil water stress on onion yield and quality in sandy soil. Misr Journal of Agricultural Engineering 24(1): 141-160.

Zhang, H. and T. Oweis. (1999). Water-yield relations and optimal irrigation scheduling of wheat in the Mediterranean region. Journal of Agricultural Water Management 38: 195-211.

Zhuo, L., M. M. Mekonnen and A. Y. Hoekstra. (2016). Benchmark levels for the consumptive water footprint of crop production for different environmental conditions: A case study for winter wheat in China, Hydrol. Earth Syst. Sci. 20: 4547-4559.

Zwart, S. J., W. G. Bastiaanssen, C. de Fraiture and D. J. Molden. (2010). A global benchmark map of water productivity for rain fed and irrigated wheat. Agricultural Water Management 97: 1617-1627. 